\title{
Novel Transgenic Rice-Based Vaccines
}

\author{
Tatsuhiko Azegami · Hiroshi Itoh · Hiroshi Kiyono • \\ Yoshikazu Yuki
}

Received: 28 January 2014 / Accepted: 26 May 2014 / Published online: 16 July 2014

(C) L. Hirszfeld Institute of Immunology and Experimental Therapy, Wroclaw, Poland 2014

\begin{abstract}
Oral vaccination can induce both systemic and mucosal antigen-specific immune responses. To control rampant mucosal infectious diseases, the development of new effective oral vaccines is needed. Plant-based vaccines are new candidates for oral vaccines, and have some advantages over the traditional vaccines in cost, safety, and scalability. Rice seeds are attractive for vaccine production because of their stability and resistance to digestion in the stomach. The efficacy of some rice-based vaccines for infectious, autoimmune, and other diseases has been already demonstrated in animal models. We reported the efficacy in mice, safety, and stability of a rice-based cholera toxin B subunit vaccine called MucoRice-CTB. To advance MucoRice-CTB for use in humans, we also examined its efficacy and safety in primates. The potential of transgenic rice production as a new mucosal vaccine delivery system is reviewed from the perspective of future development of effective oral vaccines.
\end{abstract}

Keywords Rice-based vaccine $\cdot$ MucoRice-CTB . Mucosal immunity $\cdot$ Oral vaccine

T. Azegami · H. Kiyono · Y. Yuki ( $)$

Division of Mucosal Immunology, Department of Microbiology and Immunology, The Institute of Medical Science,

The University of Tokyo, 4-6-1 Shirokanedai, Minato-ku,

Tokyo 108-8639, Japan

e-mail: yukiy@ims.u-tokyo.ac.jp

T. Azegami · H. Itoh

Department of Internal Medicine, School of Medicine, Keio

University, Tokyo, Japan

H. Kiyono · Y. Yuki

International Research and Development Center for Mucosal Vaccine, The Institute of Medical Science, The University of

Tokyo, Tokyo, Japan

\section{Introduction}

In 1798, Edward Jenner discovered that the injection of materials from cowpox protected against smallpox infection (Jenner 1798; Riedel 2005). Because dairymaids who had frequent contact with cows and had a high rate of cowpox infections were not infected with smallpox, Jenner hypothesized that cowpox infection protected against subsequent smallpox infections (Jenner 1798; Riedel 2005). As the Latin word for cow is vacca and cowpox is vaccinia, he called this new procedure vaccination (Jenner 1798). Strategies used against infectious diseases changed dramatically with the discovery of the "vaccine" by Jenner. From 1798 until now, many vaccines have played an extraordinary role in the control of numerous infectious diseases. Smallpox, which is contracted through contact and droplets, was completely eradicated by an injectable smallpox vaccine (World Health Organization 1979). However, multiple uncontrolled emerging and re-emerging infectious diseases remain throughout the world. In a survey of an estimated 8.795 million deaths in children younger than 5 years old worldwide in 2008 , infectious diseases caused $68 \%$ (5.970 million) with the largest percentages due to pneumonia $(18 \%)$ and diarrhea $(15 \%)$ (Black et al. 2010). Most pathogens that cause these respiratory and gastrointestinal infections invade the human body through mucosal interfaces by inhalation and ingestion. Therefore, the induction of protective mucosal immunity by vaccines is important for prevention of these uncontrolled mucosal infections at the site of invasion.

The traditional route of vaccine administration, subcutaneous injection, is used in vaccination against many infectious diseases. Injectable vaccines effectively induce systemic immune response, but often fail to induce sufficient mucosal immune response (Babiuk et al. 2008; Giri 
et al. 2005). In contrast, oral, intranasal, sublingual, intrarectal, and intravaginal vaccination can induce not only systemic immune response, but also protective mucosal immune response (Agnello et al. 2013; Camero et al. 2007; Kong et al. 2013; Nochi et al. 2007a; Song et al. 2008). However, there are few mucosal vaccines approved for marketing worldwide. In 2013, oral vaccines targeted only two bacterial species (Vibrio cholerae and Salmonella typhi) and two viruses (rotavirus and poliovirus. Therefore, it is necessary to develop new effective oral vaccines against infectious and other diseases.

The surfaces of mucosal tissues, especially the gastrointestinal tract, are constantly exposed to a large amount of foreign materials, including potentially harmful and undesired agents, such as pathogens, and harmless or beneficial agents, such as foods and nonpathogenic microorganisms. Recognition and subsequent uptake of these foreign antigens is an essential function of the mucosal immune system. When vaccine or pathogen antigens are delivered into the human body via mucosal surfaces, these antigens are taken up by mucosal inductive sites, known as mucosa-associated lymphoid tissues
(MALTs), which are present in the intestines and respiratory tracts. MALTs include gut-associated lymphoid tissues (GALTs) and nasopharynx-associated lymphoid tissues (NALTs) (Kunisawa et al. 2005). Both GALTs and NALTs are covered by follicle-associated epithelium consisting of a subset of differentiated microfold epithelial cells ( $\mathrm{M}$ cells), columnar epithelial cells, and lymphoid cells, which play a central role in the initiation of mucosal immune responses. $\mathrm{M}$ cells are the primary cells responsible for sampling foreign antigens and presenting them to the MALTs system (Owen 1977). The basolateral membrane of $\mathrm{M}$ cells forms pockets containing $\mathrm{T}$ lymphocytes, B lymphocytes, and dendritic cells (Takahashi et al. 2009) (Fig. 1). Upon antigen transcytosis from the intestinal tract into $\mathrm{M}$ cells, antigens are presented to dendritic cells. Subsequently, antigen-specific IgA-committed B cells and $\mathrm{T}$ cells are induced locally and then migrate via the bloodstream to distant effector sites. Therefore, transcytosis of antigens into $\mathrm{M}$ cells and their presentation to dendritic cells are necessary for the effective induction of mucosal immunity and successful oral vaccination.

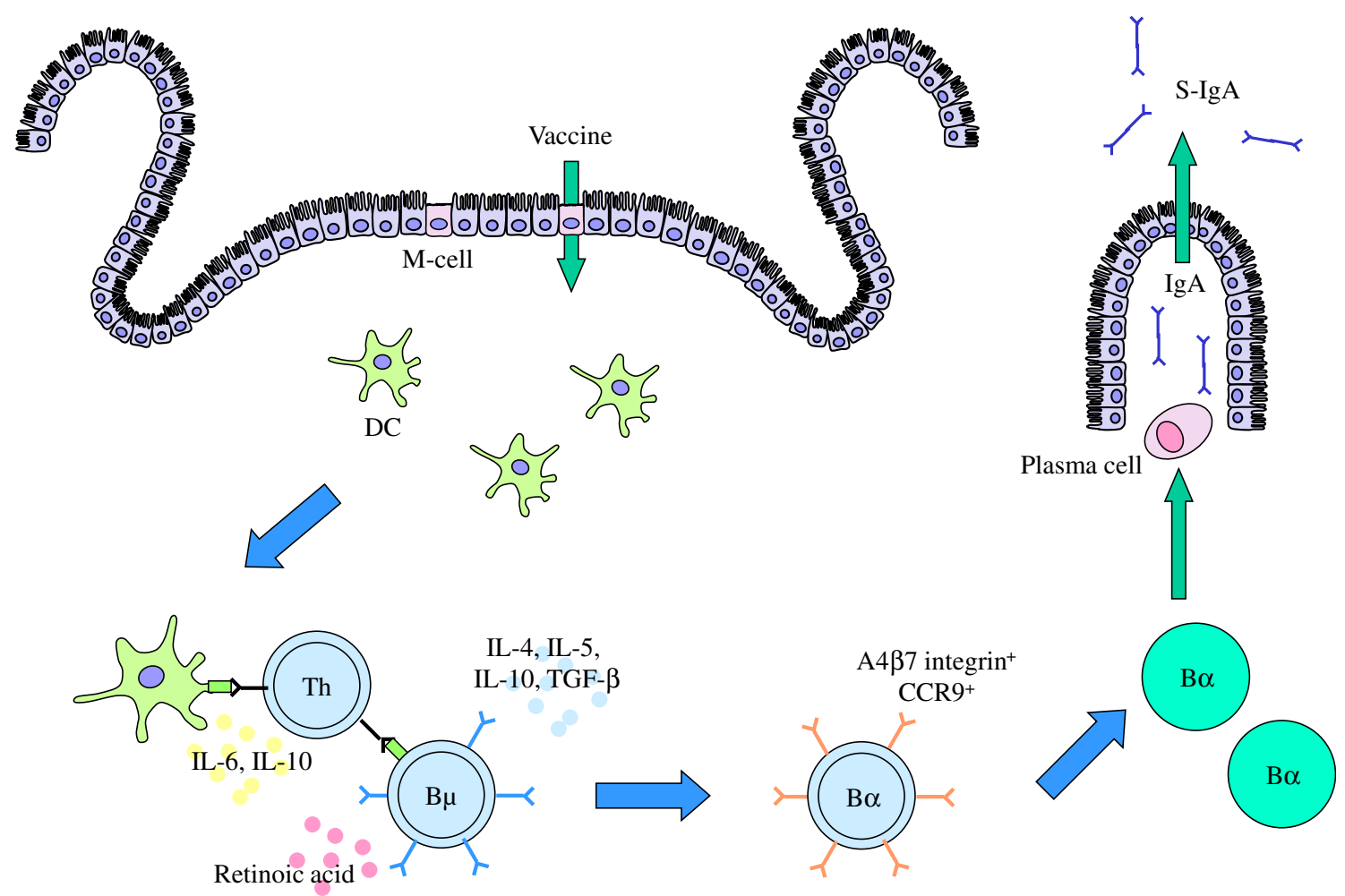

Fig. 1 Overview of the mucosal immune system. Orally administered antigens are taken up by microfold epithelial cells $(M$ cells $)$ in the follicle-associated epithelium of Peyer's patch, and presented to helper $\mathrm{T}(T h)$ cells by dendritic cells $(D C s)$. Interleukin $(I L)-4$, IL-5, IL-6, IL-10, and tumor growth factor $(T G F)-\beta$ produced by Th cells induce B cell class switch from $\mu$ to $\alpha$. Retinoic acid produced by DCs increases gut-homing receptors, such as $\alpha 4 \beta 7$-integrin and CC chemokine receptor $(C C R) 9$ on antigen-primed Th cells and IgAcommitted B cells. These antigen-primed Th cells and IgA-committed $\mathrm{B}$ cells migrate to the effector sites for terminal differentiation to IgAproducing plasma cells, and secrete secretory $\operatorname{IgA}(S-\operatorname{IgA})$ 
Table 1 Advantages and disadvantages of plant-based vaccines

References

\begin{tabular}{|c|c|c|}
\hline \multicolumn{3}{|c|}{ Advantages of plant-based vaccines } \\
\hline Safety & Low risk of contamination with human pathogens during the vaccine preparation & Minor (2012), Wirz et al. (2012) \\
\hline \multirow[t]{3}{*}{ Cost } & Low cost of production & Nochi et al. (2007a, b), Wirz et al. (2012) \\
\hline & No purification requirement (rice-based vaccine) & \\
\hline & Elimination of cost of syringes and needles (rice-based vaccine) & \\
\hline Storage & No need for cold chain during transport and storage (rice-based vaccine) & Tokuhara et al. (2010) \\
\hline Delivery & Resistance to enzymatic digestion in gastrointestinal tract (rice-based vaccine) & $\begin{array}{l}\text { Nochi et al. (2007b), Tokuhara et al. } \\
\text { (2010) }\end{array}$ \\
\hline Scaling-up & Rapid scale-up of production & Streatfield and Howard (2003) \\
\hline \multicolumn{3}{|c|}{ Disadvantages of plant-based vaccines } \\
\hline $\begin{array}{l}\text { Immune } \\
\text { response }\end{array}$ & $\begin{array}{l}\text { A risk of induction of oral tolerance after oral administration with plant-based } \\
\text { vaccines. }\end{array}$ & Kirk and Webb (2005) \\
\hline Allergen & A risk of contamination of allergenic proteins or plant-specific sugar chains & Goodman et al. (2008), van Ree (2002) \\
\hline
\end{tabular}

\section{Transgenic Plant-Based Vaccines}

In 1990, Curtiss and Cardineau expressed the Streptococcus mutans surface protein antigen A (SpaA), a causative pathogen for dental caries, in tobacco leaves (Curtiss and Cardineau 1990); this was an initial indication of a possibility of plant-based vaccines. The SpaA protein constituted approximately $0.02 \%$ of the total leaf protein. Transgenic tobacco tissue added to the diet of mice induced a mucosal immune response to the SpaA protein, and binding of the induced IgG1 monoclonal antibody to the adhesion protein of $S$. mutans was demonstrated. The authors successfully filed for and received a US Patent in 1997 (Curtiss and Cardineau 1997). In 2006, the US Department of Agriculture approved the first plant-based vaccine, which was a subunit vaccine produced in tobacco that effectively protected chickens against the Newcastle disease virus (Vermij 2006).

Since 1990 researchers have developed several edible plant-based vaccines using bacterial antigens, such as the heat-labile toxin B subunit (LTB) from enterotoxigenic Escherichia coli, cholera toxin (CT) B subunit (CTB), and antigens from Yersinia pestis and viruses, such as hepatitis $B$ virus, rotavirus, and Norwalk virus; these antigens were introduced into carrot, soybean, tomato, rice, potato, and tobacco (Jiang et al. 2007; Li et al. 2006; Moravec et al. 2007; Nochi et al. 2007b; Rosales-Mendoza et al. 2008; Santi et al. 2006; Thanavala et al. 2005; Zhang et al. 2006). Vaccines produced in plants have some advantages over traditional oral vaccines (which contain live, killed, or attenuated pathogens), including lower costs, a possibility of rapidly scaling-up production of the antigen protein, and no need for purification (Table 1). Seeds of many plants can be easily desiccated and used for antigen extraction.
Seeds are also suitable for long-term preservation of proteins without the need for the cold chain (Nochi et al. 2007b). The requirement for the cold chain is a major burden for vaccination in developing countries because of high costs, which are estimated to reach 200-300 million dollars per year worldwide (Das 2004). Rice is one of the most important food crops in the world, feeding over half of the global population (Khush 2005). Rice is also well studied, and a highly accurate complete sequence of the rice genome is available and has been already analyzed (International Rice Genome Sequence Project 2005). Therefore, rice is an attractive candidate for the development of new effective plant-based vaccines.

\section{Rice-Based Vaccines for Allergic and Autoimmune Diseases}

Rice-based vaccines for allergic and autoimmune diseases are summarized in Table 2. Takagi et al. (2005b) reported that oral immunization with transgenic rice seeds producing $\mathrm{T}$-cell epitope peptides specific for pollen allergens suppressed allergen-specific helper $\mathrm{T}$ (Th)2-mediated IgE responses and clinical symptoms of pollinosis in mice. These results demonstrated for the first time a new strategy of oral immunization with rice products. In Japan, Japanese cedar pollen is a major cause of pollinosis, with symptoms of allergic diseases, such as rhinitis and conjunctivitis (Yasueda et al. 1983). Takagi and his colleagues targeted two major allergens isolated from pollen, Cry $\mathrm{j} 1$ and Cry $\mathrm{j}$ 2 , and multiple $\mathrm{T}$-cell epitope sequences identified from these proteins (Yoshitomi et al. 2002) for their rice-based vaccine (Takagi et al. 2005b). T-cell epitope peptides of Cry j 1 and Cry j 2 were fused with the subunits of soybean 
Table 2 Rice-based vaccines for the allergic diseases and the autoimmune diseases

\begin{tabular}{|c|c|c|c|c|}
\hline Target disease & Target antigen & Expression level & Functional evaluation & References \\
\hline Cedar pollinosis & $\begin{array}{l}\text { T-cell epitopes of cedar pollen } \\
\text { (Cry j } 1 \text { and Cry j 2) with } \\
\text { soybean glycinin }\end{array}$ & $\begin{array}{l}0.5 \% \text { of total seed } \\
\text { protein }\end{array}$ & $\begin{array}{l}\text { Suppression of allergen-specific } \\
\text { IgE response and clinical } \\
\text { symptom }\end{array}$ & Takagi et al. (2005b) \\
\hline Cedar pollinosis & $\begin{array}{l}\text { T-cell epitopes of cedar pollen } \\
\text { (7Crp) with glutelin }\end{array}$ & $60 \mu \mathrm{g} /$ grain & $\begin{array}{l}\text { Suppression of allergen-specific } \\
\text { T-cell proliferative response and } \\
\text { serum IgE }\end{array}$ & $\begin{array}{l}\text { Takagi et al. (2005a, } \\
\text { 2006) }\end{array}$ \\
\hline Cedar pollinosis & $\begin{array}{l}\text { T-cell epitopes of cedar pollen } \\
\text { (Cry j } 1 \text { and Cry j 2) with CTB }\end{array}$ & $35 \mu \mathrm{g} /$ grain & $\begin{array}{l}\text { Suppression of allergen-specific } \\
\text { IgE response and clinical } \\
\text { symptoms }\end{array}$ & Takagi et al. (2008) \\
\hline Cedar pollinosis & $\begin{array}{l}\text { T-cell epitopes of cedar pollen } \\
\text { (Cry j 1) with glutelin }\end{array}$ & $\begin{array}{l}15 \% \text { of total seed } \\
\text { protein }\end{array}$ & - & Yang et al. (2007a) \\
\hline Cedar pollinosis & $\begin{array}{l}\text { Modified T-cell epitopes of cedar } \\
\text { pollen (Cry j } 1 \text { and Cry j 2) }\end{array}$ & $0.5-1.3 \mathrm{mg} / \mathrm{g}$ rice seed & $\begin{array}{l}\text { Suppression of allergen-specific } \\
\text { T-cell, IgE and IgG and clinical } \\
\text { symptoms }\end{array}$ & Wakasa et al. (2013) \\
\hline $\begin{array}{l}\text { House dust mite } \\
\text { allergy }\end{array}$ & House dust mite allergen (Der p 1) & $58 \mu \mathrm{g} /$ grain & $\begin{array}{l}\text { Inhibition of T-cell proliferative } \\
\text { response, allergen-specific IgE } \\
\text { and infiltration of eosinophils } \\
\text { into the airway }\end{array}$ & $\begin{array}{l}\text { Suzuki et al. (2009, } \\
\text { 2011), } \\
\text { Yang et al. (2008) }\end{array}$ \\
\hline Rheumatoid arthritis & Type II collagen & $1 \mu \mathrm{g} / \mathrm{seed}$ & $\begin{array}{l}\text { Suppression of specific IgG2a } \\
\text { response }\end{array}$ & $\begin{array}{l}\text { Hashizume et al. } \\
\text { (2008) }\end{array}$ \\
\hline
\end{tabular}

glycinin $\mathrm{A} 1 \mathrm{aB} 1 \mathrm{~b}$; the fusion protein accumulated at a level of $0.5 \%$ of total protein in transgenic rice seeds (Takagi et al. 2005b). Glycinin, a major soybean storage protein produced in transgenic rice under the control of rice glutelin GluB-1 promoter, colocalized with glutelins in the protein bodies (PB) (Katsube et al. 1999). To increase the antigenicity of oral vaccines, a more efficient mucosal carrier was needed. CTB was considered to be a candidate for such a carrier (Sun et al. 1994), because it is not toxic (Finkelstein and LoSpalluto 1969) and is required for binding to the specific receptor expressed in the intestine (Heyningen 1974). Therefore, the next effort was aimed to produce Cry j 1 and Cry j 2 fused with CTB in transgenic rice seeds (CTB-3Crp) (Takagi et al. 2008). Oral immunization with this new anti-allergy vaccine, CTB-3Crp, suppressed allergen-specific IgE responses and polleninduced clinical symptoms at 50-fold lower doses than T-cell epitope peptides fused with rice glutelin acidic subunit (Takagi et al. 2008). A separated study reported the efficacy of vaccination against house dust mite allergy (Yang et al. 2008). A major allergen in house dust is derived from mites of the genus Dermatophagoides (Tovey et al. 1981). The investigators expressed the allergen of $D$. pteronyssinus feces, Der $\mathrm{p} 1$, fused with the KDEL sequence, a signal for retention in the endoplasmic reticulum (ER), in rice seeds (Yang et al. 2008). C-terminal KDEL-tagged Der $\mathrm{p} 1$ accumulated in the ER-derived PB-I at $58 \mu \mathrm{g} /$ grain. Oral immunization with this protein suppressed T-cell proliferative responses in vitro, serum allergen-specific $\operatorname{IgE}$ and $\operatorname{IgG}$ responses, and accumulation of eosinophils and lymphocytes in airways in vivo (Suzuki et al. 2009, 2011).

A concept of rice-based vaccine was further extended to the control of autoimmune diseases. Hashizume et al. (2008) produced a new vaccine against type II collagen (CII), a major factor involved in the development of human rheumatoid arthritis (Trentham et al. 1977, 1978). CII expressed vaccine was produced by a fusion of four tandem repeats of a $\mathrm{CII}$ peptide containing a human $\mathrm{T}$-cell epitope with rice glutelin (gluA-4XCII $250-270)$ in transgenic rice seeds. Feeding mice with the transgenic rice seeds delayed serum CII-specific IgG2a response against injection of bovine CII (Hashizume et al. 2008).

\section{Rice-Based Vaccines for Alzheimer's Disease}

Alzheimer's disease (AD) is thought to be caused by deposition of amyloid $\beta$ protein $(A \beta)$ in the cerebral cortex (Carlson 2003; Hardy and Higgins 1992). Vaccination by injection of $\mathrm{A} \beta$ peptide is a potential therapy for $\mathrm{AD}$ in both animal models (Bard et al. 2000; Janus et al. 2000; Morgan et al. 2000; Schenk et al. 1999) and humans (Check 2002; Holmes et al. 2008). Not only injectable but also mucosal vaccines, including plant-based ones, have effects on AD in animal models (Ishii-Katsuno et al. 2010; Kim et al. 2003, 2005). Nojima and his coworkers introduced the $\mathrm{A} \beta$ gene fused with the green fluorescent protein 
Table 3 Rice-based vaccines for the infectious disease

\begin{tabular}{|c|c|c|c|c|}
\hline $\begin{array}{l}\text { Target } \\
\text { pathogen }\end{array}$ & Target antigen & Expression level & Functional evaluation & References \\
\hline Vibrio cholera & CTB subunit & $\begin{array}{l}2.1 \% \text { of total seed } \\
\text { protein }\end{array}$ & $\begin{array}{l}\text { Production of neutralizing antibody } \\
\text { against CT and protection from } \\
\text { challenging with CT }\end{array}$ & $\begin{array}{l}\text { Kurokawa et al. (2013), Nochi et al. } \\
\text { (2007b, 2009), Tokuhara et al. (2010), } \\
\text { Yuki et al. (2009, 2013) }\end{array}$ \\
\hline $\begin{array}{l}\text { Clostridium } \\
\text { botulinum }\end{array}$ & $\begin{array}{l}\text { Heavy chain of } \\
\text { botulinum type A } \\
\text { neurotoxin }\end{array}$ & $100 \mu \mathrm{g}$ per seed & $\begin{array}{l}\text { Production of neutralizing antibody } \\
\text { against BoNT/A and protection from } \\
\text { challenging with BoNT/A }\end{array}$ & Yuki et al. (2012) \\
\hline $\begin{array}{l}\text { Helicobacter } \\
\text { pylori }\end{array}$ & UreB & Unknown & - & Gu et al. (2006) \\
\hline IBDV & VP2 of IBDV & $\begin{array}{l}0.678-4.521 \% \text { of } \\
\text { total seed } \\
\text { protein }\end{array}$ & $\begin{array}{l}\text { Production of neutralizing antibody } \\
\text { against IBDV and protection from } \\
\text { challenging with virulent IBDV }\end{array}$ & Wu et al. (2007) \\
\hline NDV & $\begin{array}{l}\text { Fusion protein of } \\
\text { NDV }\end{array}$ & $\begin{array}{l}0.25-0.55 \mu \mathrm{g} \text { in } \\
200 \mu \mathrm{g} \text { of total } \\
\text { leaf and seed }\end{array}$ & Production of specific antibody & Yang et al. (2007b) \\
\hline CMV & $\begin{array}{l}\text { Glycoprotein B of } \\
\text { CMV }\end{array}$ & - & - & Tackaberry et al. (2008) \\
\hline HBV & $\begin{array}{l}\text { HBV surface } \\
\text { protein and } \\
\text { presurface one } \\
\text { region }\end{array}$ & $\begin{array}{l}31.5 \mathrm{ng} / \mathrm{g} \text { dry } \\
\text { weight grain }\end{array}$ & Production of specific antibody & Qian et al. (2008) \\
\hline $\begin{array}{l}\text { Chlamydophila } \\
\text { psittaci }\end{array}$ & $\begin{array}{l}\text { MOMP of } C \text {. } \\
\text { psittaci }\end{array}$ & $\begin{array}{r}0.0079-0.0096 \% \\
\text { of seed protein }\end{array}$ & $\begin{array}{l}\text { Production of specific antibody and } \\
\text { protection from challenging with } \\
\text { virulent } C \text {. psittaci }\end{array}$ & Zhang et al. $(2008,2009,2013)$ \\
\hline Ascaris suum & $\begin{array}{l}\text { 16-kDa protein of } \\
\text { A. suum }\end{array}$ & $50 \mu \mathrm{g} / \mathrm{g}$ seed & $\begin{array}{l}\text { Production of specific antibody and } \\
\text { protection from challenging with } A \text {. } \\
\text { suum eggs }\end{array}$ & Matsumoto et al. (2009) \\
\hline JEV & $\begin{array}{l}\text { Envelope protein of } \\
\text { JEV }\end{array}$ & $\begin{array}{l}1.1-1.9 \mu \mathrm{g} / \mathrm{mg} \text { of } \\
\text { total soluble } \\
\text { protein }\end{array}$ & $\begin{array}{l}\text { Produciton of specific neutralizing } \\
\text { antibody }\end{array}$ & Wang et al. (2009) \\
\hline FMDV & $\begin{array}{l}\text { Capsid precursor } \\
\text { polypeptide of } \\
\text { FMDV }\end{array}$ & $\begin{array}{l}0.6-1.3 \mu \mathrm{g} / \mathrm{mg} \text { of } \\
\text { total soluble } \\
\text { protein }\end{array}$ & $\begin{array}{l}\text { Produciton of specific neutralizing } \\
\text { antibody and protection from } \\
\text { challenging with FMDV }\end{array}$ & Wang et al. (2012) \\
\hline $\begin{array}{l}\text { Escherichia } \\
\text { coli }\end{array}$ & Heat-LTB of E. coli & $\begin{array}{l}0.086 \mu \mathrm{g} / \mathrm{mg} \text { of } \\
\text { lyophilized rice } \\
\text { callus }\end{array}$ & $\begin{array}{l}\text { Production of specific antibody and } \\
\text { inhibition of function of LTB }\end{array}$ & Kim et al. (2010b) \\
\hline PEDV & $\begin{array}{l}\text { Neutralizing } \\
\text { epitope region } \\
\text { (COE) of PEDV }\end{array}$ & $\begin{array}{l}0.083 \% \text { of total } \\
\text { soluble protein }\end{array}$ & $\begin{array}{l}\text { Production of specific antibody and } \\
\text { antibody-secreting cells systemically }\end{array}$ & Huy et al. (2012) \\
\hline
\end{tabular}

$C T B$ cholera toxin (CT) B subunit, IBDV infectious bursal disease virus, BoNT/A botulinum toxin type A, UreB urease subunit B, $N D V$ Newcastle disease virus, $C M V$ cytomegalovirus, $H B V$ hepatitis B virus, $M O M P$ major outer membrane protein, $J E V$ Japanese encephalitis virus, $F M D V$ foot-and-mouth disease virus, $L T B$ labile toxin B subunit, $P E D V$ porcine epidemic diarrhea virus, $C O E$ core neutralizing epitope

(GFP) gene into $O$. sativa L. cv. Hayayuki by Agrobacterium-mediated transformation, and also demonstrated that subcutaneous injection of $A \beta$ fusion protein expressed in transgenic rice improved memory in $\mathrm{Tg} 2576$ mice, an animal model of AD (Nojima et al. 2011a, b; Yoshida et al. 2011). Nojima et al. (2011b) injected subcutaneously AD model mice with the fusion protein mixed with CTB as a carrier. This induced anti-A $\beta$ antibody production, reduced $\mathrm{A} \beta$ content in both serum and brain, and improved Y-maze test results (which reflect memory). GFP fluorescence was useful to distinguish the transgenic and wild-type seeds.

\section{Rice-Based Vaccines for Infectious Diseases}

Rice-based vaccines for infectious diseases are summarized in Table 3. Gu et al. (2006) successfully produced the Helicobacter pylori urease subunit B (UreB) recombinant protein in transgenic rice. Helicobacter pylori infects the stomach, and is the main cause of gastritis, peptic ulceration, and gastric cancer (Marshall and Warren 1984; Parsonnet et al. 1991). The urease activity of $H$. pylori neutralizes stomach acidity, thus enabling $H$. pylori to colonize the stomach (Sidebotham and Baron 1990). 
UreB is thought to be a new target for $H$. pylori infection treatment, and some investigators achieved successful vaccination against UreB (Fujii et al. 2004; Yang et al. 2005). Gu et al. (2006) introduced recombinant UreB into transgenic rice by Agrobacterium-mediated transformation. Though their idea seems attractive for the development of rice-based oral vaccine against $H$. pylori infection, the authors did not report the efficacy of vaccination in vivo.

An effective rice-based vaccine for a nonhuman infectious disease was reported in 2007 (Wu et al. 2007). They targeted the infectious bursal disease virus (IBDV), which causes an immunosuppressive disease of chickens mainly by attacking an important lymphoid organ, the bursa of Fabricius (Mahgoub et al. 2012). Chickens immunized with a major IBDV protein, VP-2b, and its precursor VP-2a produced virus-neutralizing antibodies that passively protected them from IBDV infection (Fahey et al. 1989). Wu et al. (2007) cloned the VP2 cDNA from IBDV strain ZJ2000 into the binary expression vector pCambia1301Gt1, and produced the recombinant VP2 protein in transgenic rice seeds. Oral immunization with this transgenic rice successfully induced production of neutralizing antibodies against IBDV in chickens, and protected against a highly virulent IBDV strain, BC6/85.

Another effective rice-based vaccine for birds is the Fusion (F) glycoprotein of Newcastle disease virus (NDV) (Yang et al. 2007b). Newcastle disease is a life-threatening disease with mortality rates of $0.8-1.7$ per 1,000 bird-days for adult village chickens (Henning et al. 2008). The F protein is a major surface NDV glycoprotein and the principal antigen that elicits a protective immune response (Seal et al. 2000). Yang et al. (2007b) cloned the DNA encoding the NDV F protein into the binary vectors p13GN or p13UN, and transformed rice by the Agrobacteriummediated method. They successfully elicited specific antibodies in mice immunized intraperitoneally with transgenic rice plant extracts together with Freund's adjuvant.

Tackaberry et al. (2008) reported the expression of glycoprotein B of human cytomegalovirus (CMV) in transgenic rice seeds and suggested a new possibility for prevention of CMV infection, although the efficacy of vaccination in vivo was not reported. After the initial infection, CMV establishes lifelong latency in human cells, especially cells of the myeloid lineage (Gandhi and Khanna 2004). Newborn babies infected during pregnancy, and immunocompromised patients often develop uncontrolled replication of CMV. Vaccination is one of the potential strategies, and some clinical trials have been reported, including Phase II trials in pregnant women (Pass et al. 2009) and in transplant recipients (Griffiths et al. 2011). These trials used recombinant CMV glycoprotein B together with MF59 adjuvant with varying degrees of success.
High incidence rates of CMV infections in developing countries (Manicklal et al. 2013) require a reduction in the cost of vaccination against CMV. Thus, if Tackaberry and coworkers' rice-based vaccine against CMV is effective in humans, it may provide a new strategy for the control of CMV infections.

The rates of hepatitis B virus (HBV) infections are also high in developing countries, especially in Asia and Africa (Franco et al. 2012), and a cheap cold chain-free vaccine against HBV is needed. The available HBV vaccine consists of the HBV surface antigen (HBsAg) synthesized in yeast (Valenzuela et al. 1982). After the release of HBsAg vaccine on the market and initiation of the universal HBV vaccination program, the incidence of hepatocellular carcinoma greatly decreased (Chang et al. 1997). However, $11.9 \%$ of vaccinated subjects have no or inadequate levels of antibodies to HBsAg (Roome et al. 1993). Therefore, to reduce costs and improve the effectiveness, the development of a new rice-based vaccine against HBV is needed. Qian et al. (2008) introduced the modified HBsAg gene SS1 encoding the hepatocyte receptor-binding presurface 1 region (preS1) fused to the HBV surface (S) protein into rice seeds. Immune responses against both $\mathrm{S}$ and preS1 epitopes were successfully induced in mice immunized intraperitoneally with the recombinant protein derived from transgenic rice seeds.

Zhang et al. $(2008,2009)$ reported the effectiveness of a transgenic rice vaccine against Chlamydophila psittaci. Chlamydosis caused by $C$. psittaci occurs mainly in birds, but also rarely in mammals (Harkinezhad et al. 2009b). The major outer membrane protein (MOMP) of $C$. psittaci is important for maintaining the structural rigidity of the infectious form of this pathogen, and for its attachment to the host cells (Harkinezhad et al. 2009a; Vanrompay et al. 1995). Zhang et al. (2008) fused the MOMP gene of $C$. psittaci with the LTB gene and introduced the fusion gene into rice. Escherichia coli LTB, one of the two subunits of E. coli heat-labile toxin (LT), that binds to the surface of the host cells, promotes the maturation of and antigen presentation by dendritic cells, and promotes the antigenspecific cytotoxic T lymphocyte responses (Fu et al. 2009; Petrovska et al. 2003). Therefore, LTB may act as an adjuvant, making the resultant protein highly immunogenic. Oral immunization of mice with MOMP fused to LTB produced in transgenic rice seeds induced not only MOMP-specific immune responses (serum IgG, IgA, and some cytokines such as an IFN- $\gamma$ ), but also partial (approximately $50 \%$ ) protection against a lethal challenge with virulent $C$. psittaci. Recently, Zhang et al. (2013) also reported that their rice-based vaccine improved some arterial blood gas measurements in mice challenged with C. psittaci, suggesting protection from lung damage caused by $C$. psittaci. 
Matsumoto et al. (2009) reported a new rice-based vaccine against parasitic infections, especially roundworm Ascaris suum. Ascaris suum infects pigs (but not humans), resulting in a decrease in daily weight gain and an increase in feed-to-gain ratio, resulting in economic losses (Stewart and Hale 1988). Matsumoto et al. (2009) produced a $16-\mathrm{kDa}$ protein of A. suum (As16) fused with CTB in transgenic rice seeds, and demonstrated that oral immunization with the chimeric protein together with mucosal CT adjuvant induced As16-specific serum IgG antibodies and reduced the number of larvae in the lungs after infection with A. suum embryonated eggs. Human roundworm, Ascaris lumbricoides, has a protein identical to A. suum As16 (Tsuji et al. 2003). Therefore, the recombinant As16 vaccine may also prevent parasitic infections in humans.

It is estimated that $30,000-50,000$ cases of Japanese encephalitis occur each year, causing 10,000-15,000 deaths (Tsai 2000). Foot-and-mouth disease causes a contagious vesicular disease of cloven-hoofed animals (Jamal and Belsham 2013). Recently, rice-based vaccines against Japanese encephalitis virus (JEV) and foot-and-mouth disease virus (FMDV) were reported (Wang et al. 2009, 2012). The authors produced the envelope (E) protein of JEV and the precursor polypeptide (P1) of FMDV in transgenic rice leaves. The E protein of JEV is the largest structural protein in this virus; it is the major target for the humoral immune response, and is important for viral entry into human cells (Solomon 2003). The P1 protein of FMDV is thought to be an important B-cell and T-cell epitopes (Bittle et al. 1982; Rodriguez et al. 1994; Saiz et al. 1994). Intraperitoneal immunization with recombinant $\mathrm{E}$ protein produced in transgenic rice plants induced JEV-specific neutralizing antibodies, and oral immunization also induced mucosal $\operatorname{IgA}$ and $\mathrm{IgG}$ antibodies. Immunization with recombinant $\mathrm{P} 1$ produced in transgenic rice had similar results, but also led to partial virus clearance in immunized mice challenged with FMDV (Wang et al. 2012).

Rice-based vaccines against $E$. coli and porcine epidemic diarrhea virus (PEDV) were also developed (Huy et al. 2012; Kim et al. 2010b). Enteropathic E. coli is a major pathogen associated with persistent diarrhea in children in developing countries (Abba et al. 2009). As mentioned above, E. coli LTB binds to the host cells and is sometimes used as an adjuvant in vaccination. Kim et al. (2010b) inserted the LTB gene into the rice genome, and examined the recombinant protein derived from callus (but not seeds) by western blot analysis and GM1 ganglioside enzyme-linked immunosorbent assay (GM1 ELISA) (Svennerholm and Holmgren 1978); the latter assay uses the ganglioside GM1 as a specific sorbent for LT. Oral immunization with rice-based LTB vaccine elicited LTBspecific serum IgG and fecal IgA. Serum from immunized mice suppressed binding of LTB to the GM1 ganglioside receptor, suggesting that serum $\operatorname{IgG}$ inhibited the biological function of LTB.

Kim and his coworkers developed a rice-based $\mathrm{M}$ celltargeting ligand fusion protein vaccine to control PEDV infections (Huy et al. 2012). PEDV causes acute diarrhea, vomiting, and dehydration with 90-95\% mortality in pigs (Stevenson et al. 2013). The neutralizing epitope of PEDV, encoded by the core neutralizing epitope (COE) gene, was fused with the $\mathrm{M}$ cell-targeting peptide ligand Co1, which was expected to enhance the uptake of the fused antigen by M cells in Peyer's patch (Kim et al. 2010a). Mice orally immunized with the extracts of transgenic rice calli produced COE-specific serum IgG and fecal IgA antibodies; among lymphocytes isolated from the spleen, COE-specific IgG- and IgA-secreting cells were also activated, suggesting that efficient systemic and mucosal immune responses can be elicited using this approach.

We were among the first laboratories to develop an immunologically effective rice-based mucosal vaccine for an infectious disease (Nochi et al. 2007b), which is discussed in the following section.

\section{Recent Progress for the Development of MucoRice-CTB}

According to a report from the World Health Organization (2012), 58 countries reported a total of 589,854 cholera cases caused by $V$. cholerae, including 7,816 deaths (i.e., a fatality rate of $1.3 \%$ ). A higher incidence of cholera with higher mortality was observed in the developing countries. After V. cholerae is ingested, most bacteria are killed by gastric acid in the stomach; surviving organisms colonize the small intestine and produce CT (Harris et al. 2012). CT, the enterotoxin of $V$. cholerae, consists of a dimeric A subunit (CTA) and five identical B subunits, CTB. The larger of the CTA polypeptides, A1, is toxic. CTB binds tightly to GM1 ganglioside, which is abundant in the intestinal brush border membrane, and is not toxic (King and Van Heyningen 1973). Our group chose CTB as a vaccine antigen because it has been well characterized immunologically and extensively used for the analysis of antigen-specific mucosal and systemic immune responses. The CTB gene of $V$. cholerae was optimized for translation in rice and inserted into the binary vector pGPTV-35SHPT; the resultant plasmid was transformed into $O$. sativa L. cv. Kitaake or Nipponbare by the Agrobacterium-mediated method. Recombinant CTB content reached an average of $30 \mu \mathrm{g}$ per transgenic rice seed, representing $2.1 \%$ of the total seed protein $(0.15 \%$ of seed weight). Immunoelectron microscopic analysis and western blot analysis indicated that CTB accumulated in rice PB-I and 
PB-II and was protected from pepsin digestion. In contrast, purified recombinant CTB (produced in bacteria, not in rice) was almost completely digested by pepsin treatment. Therefore, rice-based vaccine is an effective delivery vehicle for oral immunization. In addition to resistance of recombinant rice protein to gastric acid, we confirmed the uptake of orally administered CTB from $M$ cells using immunohistochemistry with an anti-CTB antibody and Ulex europaeus agglutinin, which is a known marker for murine M cells (Clark et al. 1993). These findings demonstrate that MucoRice-CTB can be considered as a nextgeneration plant-based effective oral vaccine that can deliver vaccine antigen to the inductive site.

For the immunogenicity of MucoRice-CTB, mice were initially employed for oral vaccination studies. CTB-specific serum IgG and fecal IgA antibodies were detected in mice orally immunized with MucoRice-CTB, indicating that oral immunization with MucoRice-CTB could induce not only systemic but also mucosal immune response. To confirm the CT-neutralizing activity of serum IgG antibody after immunization with MucoRice-CTB, serum samples were subjected to the commonly used GM1-ELISA (Svennerholm and Holmgren 1978) and an elongation assay with Chinese hamster ovary (CHO) cells (Guerrant et al. 1974). In GM1-ELISA analysis, serum samples mixed with CT were incubated in GM1-coated plates and then evaluated by ELISA with an anti-CTB antibody. GM1-ELISA revealed that serum from mice orally immunized with MucoRice-CTB inhibited CT binding to GM1 ganglioside. The $\mathrm{CHO}$ elongation assay revealed no morphological changes in $\mathrm{CHO}$ cells incubated with $\mathrm{CT}$ pretreated with serum from mice orally vaccinated with MucoRice-CTB, suggesting that serum antibodies from these mice successfully neutralized CT. In addition to these in vitro experiments, an in vivo experiment showed that mice immunized with MucoRice-CTB showed no clinical signs of diarrhea when orally challenged with CT. The finding further demonstrated that oral MucoRice-CTB induced gut IgA antibodies possessed neutralizing activities against $\mathrm{CT}$.

In addition to these advantages on induction of protective immunity, MucoRice-CTB has another advantage of long-term storage without refrigerator. In our experiments, oral immunization with MucoRice-CTB stored at room temperature for more than 3 years induced CTB-specific serum IgG and fecal IgA at the same level as freshly harvested MucoRice-CTB. This feature of MucoRice-CTB means that it has a great advantage of being able to be stored even in developing countries in the absence of cold chain.

We also clarified several advantageous points that may affect the future use of MucoRice-CTB in humans. Because the duration of protective immunity is an important issue for vaccination, we examined the time course of CTB-specific serum IgG and fecal IgA antibody titers after oral immunization with MucoRice-CTB (Tokuhara et al. 2010). Although the levels of CTB-specific serum $\operatorname{IgG}$ remained high during the 6 months after oral immunization (repeated four times) with MucoRiceCTB, fecal IgA gradually decreased and the IgA titers at six months were half the level shortly after vaccination. However, partial protection against CT challenge remained at 6 months, and a single oral booster vaccination with MucoRice-CTB restored CTB-specific fecal IgA to the same levels as shortly after vaccination. Whether MucoRice-CTB can also induce cross-protective immunity against LT is another important issue, because, as mentioned above, enteropathic E. coli is commonly found in developing countries in children (up to $63 \%$ ) with persistent diarrhea (Abba et al. 2009). Oral immunization with MucoRice-CTB reduced the incidence of LT-producing enteropathic E. coli-induced diarrhea (Tokuhara et al. 2010). In addition, before using MucoRice-CTB in human clinical studies, it is necessary to examine its immunogenicity and safety in nonhuman primates. We examined whether vaccination with MucoRice-CTB would induce a mucosal immune response to CTB in cynomolgus macaques (Macaca fascicularis) (Nochi et al. 2009). As expected, the levels of CTB-specific serum IgG in macaques orally immunized with MucoRice-CTB increased, and the IgG antibodies showed toxin-neutralizing activity in GM1-ELISA. No allergic immune responses or other adverse effects were noticed.

To rule out the possibility of an unexpected increase in rice allergen protein production in MucoRice-CTB, we compared the levels of allergen proteins in MucoRice-CTB and wild-type rice using two-dimensional fluorescence difference gel electrophoresis (2D-DIGE) and shotgun MS/ MS proteomics (Kurokawa et al. 2013). 2D-DIGE is a protein labeling and separation technique that uses optical fluorescence detection of differentially labeled proteins separated on the same gel (Timms and Cramer 2008). We found that the amount of the major rice allergens, members of the $\alpha$-amylase/trypsin inhibitor-like protein family (Adachi et al. 1993; Nakamura and Matsuda 1996), was lower in MucoRice-CTB than in wild-type rice, Nipponbare. We also performed shotgun MS/MS proteomics, which is a label-free quantification method (Lee and Koh 2011), and found that the amount of IgE-binding allergen proteins was similar or lower in MucoRice-CTB than in wild-type rice. These findings further demonstrated that allergen aspect of concern for MucoRice-CTB is minimized to none.

To advance the MucoRice production system further, our attempt was extended to express antigens with higher molecular weight than CTB (monomer, $11 \mathrm{kDa}$ ). Among 


\section{Tandem T-DNA vector for BoHc Expression in Rice (MucoRice-BoHc)}

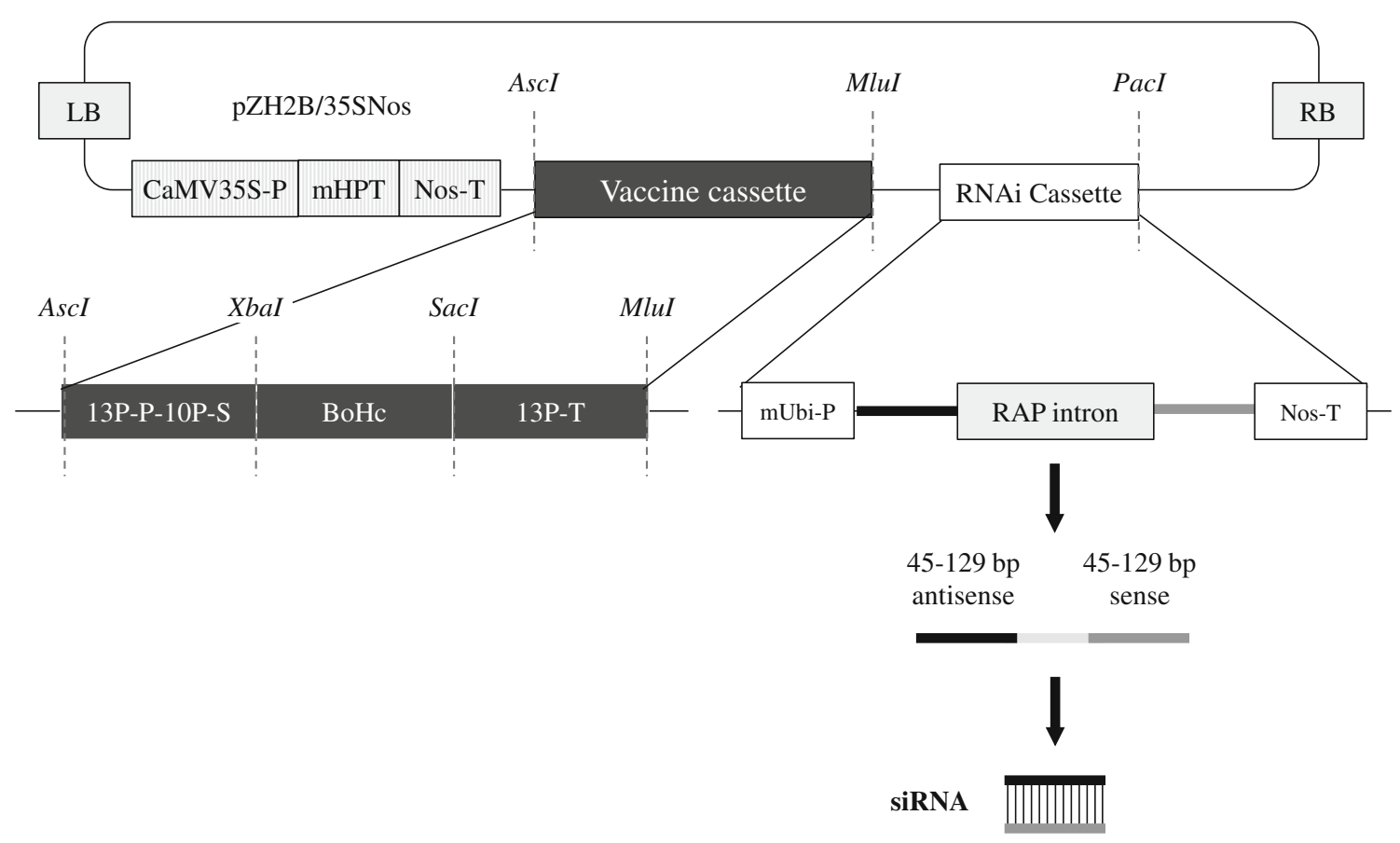

Fig. 2 T-DNA vector for RNAi-mediated suppression of rice storage proteins and overexpression of $\mathrm{BoHc}$ in rice seeds. A tandem T-DNA plasmid vector contains a BoHc overexpression cassette (vaccine cassette) with the sequence encoding the $\mathrm{BoHc}$ antigen under the control of the promoter of rice $13-\mathrm{kDa}$ prolamin, and an RNAi cassette, including antisense sequence (45-129 bp) specific for endogenous rice storage protein, for suppression of major endogenous proteins, $13-\mathrm{kDa}$ prolamin and glutelin, under the control of the

pathogens and toxins that can be absorbed from the mucosal surface, we chose a nontoxic $45-\mathrm{kDa}$ fragment of the C-terminal half of the heavy chain of botulinum neurotoxin type A $(\mathrm{BoHc})$ and successfully obtained MucoRice-BoHc, which induced protective immunity against BoHc in mice (Yuki et al. 2012). To achieve higher levels of production of this antigen by suppressing the endogenous rice proteins, we attempted to suppress $13-\mathrm{kDa}$ prolamin and glutelin A by RNAi. Suppression of production of these proteins substantially improved the BoHc accumulation $(100 \mu \mathrm{g} / \mathrm{seed})$ in comparison with seeds without RNAi (10 $\mu \mathrm{g} / \mathrm{seed})$ (Fig. 2).

In transgenic rice seeds, CTB is $N$-glycosylated at Asn32 with a plant-specific $N$-glycan carrying $\beta 1,2$-xylose or $\alpha 1,3$-fucose residues (Kajiura et al. 2013). These residues strongly contribute to IgE binding to glycoallergens (van Ree et al. 2000). Therefore, we substituted Asn with Gln in a CTB glycosylation sites to prevent plant-specific glycosylation of CTB (MucoRice-CTB/Q) (Yuki et al. 2013). We confirmed that in macaques the resultant MucoRice-CTB/Q vaccine induced similar levels of CTB- ubiquitin promoter. $L B$ T-DNA left border, CaMV35S-P cauliflower mosaic virus $35 \mathrm{~S}$ promoter, $m H P T$ mutant hygromycin phosphotransferase, Nos-T nos terminator, $13 P-P 13-\mathrm{kDa}$ prolamin promoter, $10 P-S$ signal sequence of $10-\mathrm{kDa}$ prolamin, $\mathrm{BoHc} 45-\mathrm{kDa}$ fragment of C-terminal half of the heavy chain of botulinum neurotoxin type A, $13 P-T 13-\mathrm{kDa}$ prolamin terminator, $m U b i-P$ ubiquitin promoter, $R A P$ intron rice aspartic protease intron, $R B$ T-DNA right border. Restriction endonuclease sites are italicized

specific systemic IgG and mucosal IgA antibodies with toxin-neutralizing activity as the original MucoRice-CTB. As a result of the removal of the plant $N$-glycan, MucoRice-CTB/Q is expected to be a safer mucosal vaccine of equivalent immunogenicity with the original one.

\section{Conclusion}

Mucosal vaccination, such as oral, intranasal, sublingual, intrarectal, and intravaginal immunization, can induce not only systemic immune response, but also protective mucosal immune response. Development of new delivery system that effectively induces transcytosis of antigens into $M$ cells and their presentation to dendritic cells are necessary for the successful mucosal vaccination. Plant-based vaccine is one of potential candidates for new mucosal vaccine because of their advantages in stability, safety, and scalability. The plant-based expression systems are thought to be a very safe system because they have low risk of contamination with human pathogens during the vaccine 
preparation. Especially, rice has some advantages over other plants in terms of vaccine production. CTB-antigens produced in rice seeds remain stable for at least 3 years without cold chain, are protected from digestion in the stomach, and are efficiently taken up by $\mathrm{M}$ cells. These findings suggest rice-based vaccines are shelf-stable and effective antigen-delivery system for induction mucosal immune responses. In addition to protective effect of ricebased vaccines against infectious diseases, immunization with allergens or self-antigens produced in rice seed could also prevent allergic diseases or autoimmune diseases by the induction of immune tolerance in animal models. Therefore, the rice-based vaccine is a new candidate for efficient, safe and cost-effective vaccine.

\section{References}

Abba K, Sinfield R, Hart CA et al (2009) Pathogens associated with persistent diarrhoea in children in low and middle income countries: systematic review. BMC Infect Dis 9:88

Adachi T, Izumi H, Yamada T et al (1993) Gene structure and expression of rice seed allergenic proteins belonging to the alphaamylase/trypsin inhibitor family. Plant Mol Biol 21:239-248

Agnello D, Denimal D, Lavaux A et al (2013) Intrarectal immunization and IgA antibody-secreting cell homing to the small intestine. J Immunol 190:4836-4847

Babiuk S, Asper DJ, Rogan D et al (2008) Subcutaneous and intranasal immunization with type III secreted proteins can prevent colonization and shedding of Escherichia coli O157:H7 in mice. Microb Pathog 45:7-11

Bard F, Cannon C, Barbour R et al (2000) Peripherally administered antibodies against amyloid beta-peptide enter the central nervous system and reduce pathology in a mouse model of Alzheimer disease. Nat Med 6:916-919

Bittle JL, Houghten RA, Alexander H et al (1982) Protection against foot-and-mouth disease by immunization ith a chemically synthesized peptide predicted from the viral nucleotide sequence. Nature 298:30-33

Black RE, Cousens S, Johnson HL et al (2010) Global, regional, and national causes of child mortality in 2008: a systematic analysis. Lancet 375:1969-1987

Camero M, Bellacicco AL, Tarsitano E et al (2007) Intravaginal administration of an inactivated vaccine prevents lesions induced by caprine herpesvirus- 1 in goats. Vaccine $25: 1658-1661$

Carlson GA (2003) A welcoming environment for amyloid plaques. Nat Neurosci 6:328-330

Chang MH, Chen CJ, Lai MS et al (1997) Universal hepatitis B vaccination in Taiwan and the incidence of hepatocellular carcinoma in children. Taiwan Childhood Hepatoma Study Group. N Engl J Med 336:1855-1859

Check E (2002) Nerve inflammation halts trial for Alzheimer's drug. Nature 415:462

Clark MA, Jepson MA, Simmons NL et al (1993) Differential expression of lectin-binding sites defines mouse intestinal M-cells. J Histochem Cytochem 41:1679-1687

Curtiss R, Cardineau C (1990) Oral immunization by transgenic plants. World Patent Application, WO 90/02484. Patent record available from the World Intellectual Property Organization (WIPO)
Curtiss R, Cardineau G (1997) Oral immunization by transgenic plants. Google Patents

Das P (2004) Revolutionary vaccine technology breaks the cold chain. Lancet Infect Dis 4:719

Fahey KJ, Erny K, Crooks J (1989) A conformational immunogen on VP-2 of infectious bursal disease virus that induces virusneutralizing antibodies that passively protect chickens. J Gen Virol 70(Pt 6):1473-1481

Finkelstein RA, LoSpalluto JJ (1969) Pathogenesis of experimental cholera. Preparation and isolation of choleragen and choleragenoid. J Exp Med 130:185-202

Franco E, Bagnato B, Marino MG et al (2012) Hepatitis B: epidemiology and prevention in developing countries. World $\mathrm{J}$ Hepatol 4:74-80

$\mathrm{Fu} \mathrm{N}$, Khan S, Quinten E et al (2009) Effective CD8(+) T cell priming and tumor protection by enterotoxin B subunit-conjugated peptides targeted to dendritic cells. Vaccine 27:5252-5258

Fujii R, Morihara F, Fukushima K et al (2004) Recombinant antigen from Helicobacter pylori urease as vaccine against $H$. pyloriassociated disease. Biotechnol Bioeng 86:737-746

Gandhi MK, Khanna R (2004) Human cytomegalovirus: clinical aspects, immune regulation, and emerging treatments. Lancet Infect Dis 4:725-738

Giri PK, Sable SB, Verma I et al (2005) Comparative evaluation of intranasal and subcutaneous route of immunization for development of mucosal vaccine against experimental tuberculosis. FEMS Immunol Med Microbiol 45:87-93

Goodman RE, Vieths S, Sampson HA et al (2008) Allergenicity assessment of genetically modified crops-what makes sense? Nat Biotechnol 26:73-81

Griffiths PD, Stanton A, McCarrell E et al (2011) Cytomegalovirus glycoprotein-B vaccine with MF59 adjuvant in transplant recipients: a phase 2 randomised placebo-controlled trial. Lancet 377:1256-1263

Gu Q, Han N, Liu J et al (2006) Expression of Helicobacter pylori urease subunit $\mathrm{B}$ gene in transgenic rice. Biotechnol Lett 28:1661-1666

Guerrant RL, Brunton LL, Schnaitman TC et al (1974) Cyclic adenosine monophosphate and alteration of Chinese hamster ovary cell morphology: a rapid, sensitive in vitro assay for the enterotoxins of Vibrio cholerae and Escherichia coli. Infect Immun 10:320-327

Hardy JA, Higgins GA (1992) Alzheimer's disease: the amyloid cascade hypothesis. Science 256:184-185

Harkinezhad T, Geens T, Vanrompay D (2009a) Chlamydophila psittaci infections in birds: a review with emphasis on zoonotic consequences. Vet Microbiol 135:68-77

Harkinezhad T, Verminnen K, De Buyzere M et al (2009b) Prevalence of Chlamydophila psittaci infections in a human population in contact with domestic and companion birds. J Med Microbiol 58:1207-1212

Harris JB, LaRocque RC, Qadri F et al (2012) Cholera. Lancet 379:2466-2476

Hashizume F, Hino S, Kakehashi M et al (2008) Development and evaluation of transgenic rice seeds accumulating a type IIcollagen tolerogenic peptide. Transgenic Res 17:1117-1129

Henning J, Morton J, Hla T et al (2008) Mortality rates adjusted for unobserved deaths and associations with Newcastle disease virus serology among unvaccinated village chickens in Myanmar. Prev Vet Med 85:241-252

Holmes C, Boche D, Wilkinson D et al (2008) Long-term effects of Abeta42 immunisation in Alzheimer's disease: follow-up of a randomised, placebo-controlled phase I trial. Lancet 372:216-223

Huy NX, Kim SH, Yang MS et al (2012) Immunogenicity of a neutralizing epitope from porcine epidemic diarrhea virus: $M$ 
cell targeting ligand fusion protein expressed in transgenic rice calli. Plant Cell Rep 31:1933-1942

International Rice Genome Sequence Project (2005) The map-based sequence of the rice genome. Nature 436:793-800

Ishii-Katsuno R, Nakajima A, Katsuno T et al (2010) Reduction of amyloid beta-peptide accumulation in $\mathrm{Tg} 2576$ transgenic mice by oral vaccination. Biochem Biophys Res Commun 399:593-599

Jamal SM, Belsham GJ (2013) Foot-and-mouth disease: past, present and future. Vet Res 44:116

Janus C, Pearson J, McLaurin J et al (2000) A beta peptide immunization reduces behavioural impairment and plaques in a model of Alzheimer's disease. Nature 408:979-982

Jenner E (1798) An inquiry into the causes and effects of the Variolae Vaccinae. Sampson Low, London Republished by Cassell, London, p 1876

Jiang XL, He ZM, Peng ZQ et al (2007) Cholera toxin B protein in transgenic tomato fruit induces systemic immune response in mice. Transgenic Res 16:169-175

Kajiura H, Wasai M, Kasahara S et al (2013) $N$-glycosylation and $N$ glycan moieties of CTB expressed in rice seeds. Mol Biotechnol 54:784-794

Katsube T, Kurisaka N, Ogawa M et al (1999) Accumulation of soybean glycinin and its assembly with the glutelins in rice. Plant Physiol 120:1063-1074

Khush GS (2005) What it will take to feed 5.0 billion rice consumers in 2030. Plant Mol Biol 59:1-6

Kim HS, Euym JW, Kim MS et al (2003) Expression of human betaamyloid peptide in transgenic potato. Plant Sci 165:1445-1451

Kim HD, Cao Y, Kong FK et al (2005) Induction of a Th2 immune response by co-administration of recombinant adenovirus vectors encoding amyloid beta-protein and GM-CSF. Vaccine 23:2977-2986

Kim SH, Seo KW, Kim J et al (2010a) The M cell-targeting ligand promotes antigen delivery and induces antigen-specific immune responses in mucosal vaccination. $\mathbf{J}$ Immunol 185:5787-5795

Kim TG, Kim BG, Kim MY et al (2010b) Expression and immunogenicity of enterotoxigenic Escherichia coli heat-labile toxin $\mathrm{B}$ subunit in transgenic rice callus. Mol Biotechnol 44:14-21

King CA, Van Heyningen WE (1973) Deactivation of cholera toxin by a sialidase-resistant monosialosylganglioside. J Infect Dis 127:639-647

Kirk DD, Webb SR (2005) The next 15 years: taking plant-made vaccines beyond proof of concept. Immunol Cell Biol $83: 248-256$

Kong IG, Sato A, Yuki Y et al (2013) Nanogel-based PspA intranasal vaccine prevents invasive disease and nasal colonization by Streptococcus pneumoniae. Infect Immun 81:1625-1634

Kunisawa J, Fukuyama S, Kiyono H (2005) Mucosa-associated lymphoid tissues in the aerodigestive tract: their shared and divergent traits and their importance to the orchestration of the mucosal immune system. Curr Mol Med 5:557-572

Kurokawa S, Nakamura R, Mejima M et al (2013) MucoRice-cholera toxin B-subunit, a rice-based oral cholera vaccine, downregulates the expression of alpha-amylase/trypsin inhibitor-like protein family as major rice allergens. J Proteome Res $12: 3372-3382$

Lee J, Koh HJ (2011) A label-free quantitative shotgun proteomics analysis of rice grain development. Proteome Sci 9:61

Li JT, Fei L, Mou ZR et al (2006) Immunogenicity of a plant-derived edible rotavirus subunit vaccine transformed over fifty generations. Virology 356:171-178

Mahgoub HA, Bailey M, Kaiser P (2012) An overview of infectious bursal disease. Arch Virol 157:2047-2057
Manicklal S, Emery VC, Lazzarotto T et al (2013) The "silent" global burden of congenital cytomegalovirus. Clin Microbiol Rev 26:86-102

Marshall BJ, Warren JR (1984) Unidentified curved bacilli in the stomach of patients with gastritis and peptic ulceration. Lancet $1: 1311-1315$

Matsumoto Y, Suzuki S, Nozoye T et al (2009) Oral immunogenicity and protective efficacy in mice of transgenic rice plants producing a vaccine candidate antigen (As16) of Ascaris suum fused with cholera toxin B subunit. Transgenic Res 18:185-192

Minor P (2012) Considerations for setting the specifications of vaccines. Expert Rev Vaccines 11:579-585

Moravec T, Schmidt MA, Herman EM et al (2007) Production of Escherichia coli heat labile toxin (LT) B subunit in soybean seed and analysis of its immunogenicity as an oral vaccine. Vaccine 25:1647-1657

Morgan D, Diamond DM, Gottschall PE et al (2000) A beta peptide vaccination prevents memory loss in an animal model of Alzheimer's disease. Nature 408:982-985

Nakamura R, Matsuda T (1996) Rice allergenic protein and molecular-genetic approach for hypoallergenic rice. Biosci Biotechnol Biochem 60:1215-1221

Nochi T, Yuki Y, Matsumura A et al (2007a) A novel M cell-specific carbohydrate-targeted mucosal vaccine effectively induces antigen-specific immune responses. J Exp Med 204:2789-2796

Nochi T, Takagi H, Yuki Y et al (2007b) Rice-based mucosal vaccine as a global strategy for cold-chain- and needle-free vaccination. Proc Natl Acad Sci USA 104:10986-10991

Nochi T, Yuki Y, Katakai Y et al (2009) A rice-based oral cholera vaccine induces macaque-specific systemic neutralizing antibodies but does not influence pre-existing intestinal immunity. J Immunol 183:6538-6544

Nojima J, Ishii-Katsuno R, Futai E et al (2011a) Production of antiamyloid beta antibodies in mice fed rice expressing amyloid beta. Biosci Biotechnol Biochem 75:396-400

Nojima J, Maeda A, Aoki S et al (2011b) Effect of rice-expressed amyloid beta in the $\mathrm{Tg} 2576$ Alzheimer's disease transgenic mouse model. Vaccine 29:6252-6258

Owen RL (1977) Sequential uptake of horseradish peroxidase by lymphoid follicle epithelium of Peyer's patches in the normal unobstructed mouse intestine: an ultrastructural study. Gastroenterology 72:440-451

Parsonnet J, Friedman GD, Vandersteen DP et al (1991) Helicobacter pylori infection and the risk of gastric carcinoma. N Engl J Med 325:1127-1131

Pass RF, Zhang C, Evans A et al (2009) Vaccine prevention of maternal cytomegalovirus infection. $\mathrm{N}$ Engl J Med 360:1191-1199

Petrovska L, Lopes L, Simmons CP et al (2003) Modulation of dendritic cell endocytosis and antigen processing pathways by Escherichia coli heat-labile enterotoxin and mutant derivatives. Vaccine 21:1445-1454

Qian B, Shen H, Liang W et al (2008) Immunogenicity of recombinant hepatitis $B$ virus surface antigen fused with preS1 epitopes expressed in rice seeds. Transgenic Res 17:621-631

Riedel S (2005) Edward Jenner and the history of smallpox and vaccination. Proc (Bayl Univ Med Cent) 18:21-25

Rodriguez A, Saiz JC, Novella IS et al (1994) Antigenic specificity of porcine $\mathrm{T}$ cell response against foot-and-mouth disease virus structural proteins: identification of T helper epitopes in VP1. Virology 205:24-33

Roome AJ, Walsh SJ, Cartter ML et al (1993) Hepatitis B vaccine responsiveness in Connecticut public safety personnel. JAMA 270:2931-2934

Rosales-Mendoza S, Soria-Guerra RE, Lopez-Revilla R et al (2008) Ingestion of transgenic carrots expressing the Escherichia coli 
heat-labile enterotoxin B subunit protects mice against cholera toxin challenge. Plant Cell Rep 27:79-84

Saiz JC, Cairo J, Medina M et al (1994) Unprocessed foot-and-mouth disease virus capsid precursor displays discontinuous epitopes involved in viral neutralization. J Virol 68:4557-4564

Santi L, Giritch A, Roy CJ et al (2006) Protection conferred by recombinant Yersinia pestis antigens produced by a rapid and highly scalable plant expression system. Proc Natl Acad Sci USA 103:861-866

Schenk D, Barbour R, Dunn W et al (1999) Immunization with amyloid-beta attenuates Alzheimer-disease-like pathology in the PDAPP mouse. Nature 400:173-177

Seal BS, King DJ, Sellers HS (2000) The avian response to Newcastle disease virus. Dev Comp Immunol 24:257-268

Sidebotham RL, Baron JH (1990) Hypothesis: Helicobacter pylori, urease, mucus, and gastric ulcer. Lancet 335:193-195

Solomon T (2003) Recent advances in Japanese encephalitis. J Neurovirol 9:274-283

Song JH, Nguyen HH, Cuburu N et al (2008) Sublingual vaccination with influenza virus protects mice against lethal viral infection. Proc Natl Acad Sci USA 105:1644-1649

Stevenson GW, Hoang H, Schwartz KJ et al (2013) Emergence of Porcine epidemic diarrhea virus in the United States: clinical signs, lesions, and viral genomic sequences. J Vet Diagn Invest 25:649-654

Stewart TB, Hale OM (1988) Losses to internal parasites in swine production. J Anim Sci 66:1548-1554

Streatfield SJ, Howard JA (2003) Plant-based vaccines. Int J Parasitol 33:479-493

Sun JB, Holmgren J, Czerkinsky C (1994) Cholera toxin B subunit: an efficient transmucosal carrier-delivery system for induction of peripheral immunological tolerance. Proc Natl Acad Sci USA 91:10795-10799

Suzuki K, Kaminuma O, Yang L et al (2009) Development of transgenic rice expressing mite antigen for a new concept of immunotherapy. Int Arch Allergy Immunol 149:21-24

Suzuki K, Kaminuma O, Yang LJ et al (2011) Prevention of allergic asthma by vaccination with transgenic rice seed expressing mite allergen: induction of allergen-specific oral tolerance without bystander suppression. Plant Biotechnol J 9:982-990

Svennerholm AM, Holmgren J (1978) Identification of Escherichia coli heat-labile enterotoxin by means of a ganglioside immunosorbent assay (Gm1-Elisa) procedure. Curr Microbiol 1:19-23

Tackaberry ES, Prior FA, Rowlandson K et al (2008) Sustained expression of human cytomegalovirus glycoprotein B (UL55) in the seeds of homozygous rice plants. Mol Biotechnol 40:1-12

Takagi H, Saito S, Yang L et al (2005a) Oral immunotherapy against a pollen allergy using a seed-based peptide vaccine. Plant Biotechnol J 3:521-533

Takagi H, Hiroi T, Yang L et al (2005b) A rice-based edible vaccine expressing multiple $\mathrm{T}$ cell epitopes induces oral tolerance for inhibition of Th2-mediated IgE responses. Proc Natl Acad Sci USA 102:17525-17530

Takagi H, Hirose S, Yasuda $\mathrm{H}$ et al (2006) Biochemical safety evaluation of transgenic rice seeds expressing $\mathrm{T}$ cell epitopes of Japanese cedar pollen allergens. J Agric Food Chem 54:9901-9905

Takagi H, Hiroi T, Yang L et al (2008) Efficient induction of oral tolerance by fusing cholera toxin B subunit with allergenspecific T-cell epitopes accumulated in rice seed. Vaccine 26:6027-6030

Takahashi I, Nochi T, Yuki Y et al (2009) New horizon of mucosal immunity and vaccines. Curr Opin Immunol 21:352-358

Thanavala Y, Mahoney M, Pal S et al (2005) Immunogenicity in humans of an edible vaccine for hepatitis B. Proc Natl Acad Sci USA 102:3378-3382
Timms JF, Cramer R (2008) Difference gel electrophoresis. Proteomics 8:4886-4897

Tokuhara D, Yuki Y, Nochi T et al (2010) Secretory IgA-mediated protection against $V$. cholerae and heat-labile enterotoxinproducing enterotoxigenic Escherichia coli by rice-based vaccine. Proc Natl Acad Sci USA 107:8794-8799

Tovey ER, Chapman MD, Platts-Mills TA (1981) Mite faeces are a major source of house dust allergens. Nature 289:592-593

Trentham DE, Townes AS, Kang AH (1977) Autoimmunity to type II collagen an experimental model of arthritis. J Exp Med 146:857-868

Trentham DE, Dynesius RA, Rocklin RE et al (1978) Cellular sensitivity to collagen in rheumatoid arthritis. $\mathrm{N}$ Engl $\mathrm{J}$ Med 299:327-332

Tsai TF (2000) New initiatives for the control of Japanese encephalitis by vaccination: minutes of a WHO/CVI meeting, Bangkok, Thailand, 13-15 October 1998. Vaccine 18(Suppl 2):1-25

Tsuji N, Suzuki K, Kasuga-Aoki H et al (2003) Mice intranasally immunized with a recombinant 16-kilodalton antigen from roundworm Ascaris parasites are protected against larval migration of Ascaris suum. Infect Immun 71:5314-5323

Valenzuela P, Medina A, Rutter WJ et al (1982) Synthesis and assembly of hepatitis B virus surface antigen particles in yeast. Nature 298:347-350

Van Heyningen S (1974) Cholera toxin: interaction of subunits with ganglioside GM1. Science 183:656-657

van Ree R (2002) Carbohydrate epitopes and their relevance for the diagnosis and treatment of allergic diseases. Int Arch Allergy Immunol 129:189-197

van Ree R, Cabanes-Macheteau M, Akkerdaas J et al (2000) Beta(1,2)-xylose and alpha(1,3)-fucose residues have a strong contribution in IgE binding to plant glycoallergens. J Biol Chem 275:11451-11458

Vanrompay D, Ducatelle R, Haesebrouck F (1995) Chlamydia psittaci infections: a review with emphasis on avian chlamydiosis. Vet Microbiol 45:93-119

Vermij P (2006) USDA approves the first plant-based vaccine. Nat Biotechnol 24:234

Wakasa Y, Takagi H, Hirose S et al (2013) Oral immunotherapy with transgenic rice seed containing destructed Japanese cedar pollen allergens, Cry j 1 and Cry j 2, against Japanese cedar pollinosis. Plant Biotechnol J 11:66-76

Wang Y, Deng H, Zhang X et al (2009) Generation and immunogenicity of Japanese encephalitis virus envelope protein expressed in transgenic rice. Biochem Biophys Res Commun 380:292-297

Wang Y, Shen Q, Jiang Y et al (2012) Immunogenicity of foot-andmouth disease virus structural polyprotein P1 expressed in transgenic rice. J Virol Methods 181:12-17

Wirz H, Sauer-Budge AF, Briggs J et al (2012) Automated production of plant-based vaccines and pharmaceuticals. J Lab Autom 17:449-457

World Health Organization (1979) Global Commission for the Certification of Smallpox Eradication. The global eradication of smallpox: final report of the Global Commission for the Certification of Smallpox Eradication, December 1979, Geneva

World Health Organization (2012) Cholera, 2011. Wkly Epidemiol Rec 87:289-304

Wu JX, Yu L, Li L et al (2007) Oral immunization with transgenic rice seeds expressing VP2 protein of infectious bursal disease virus induces protective immune responses in chickens. Plant Biotechnol J 5:570-578

Yang XL, Liu WC, Yang WW et al (2005) Oral immunization of mice with vaccine of attenuated Salmonella typhimurium expressing Helicobacter pylori urease B subunit. Biomed Environ Sci 18:411-418 
Yang L, Suzuki K, Hirose S et al (2007a) Development of transgenic rice seed accumulating a major Japanese cedar pollen allergen (Cry j 1) structurally disrupted for oral immunotherapy. Plant Biotechnol J 5:815-826

Yang ZQ, Liu QQ, Pan ZM et al (2007b) Expression of the fusion glycoprotein of Newcastle disease virus in transgenic rice and its immunogenicity in mice. Vaccine 25:591-598

Yang L, Kajiura H, Suzuki K et al (2008) Generation of a transgenic rice seed-based edible vaccine against house dust mite allergy. Biochem Biophys Res Commun 365:334-339

Yasueda H, Yui Y, Shimizu T et al (1983) Isolation and partial characterization of the major allergen from Japanese cedar (Cryptomeria japonica) pollen. J Allergy Clin Immunol 71:77-86

Yoshida T, Kimura E, Koike S et al (2011) Transgenic rice expressing amyloid beta-peptide for oral immunization. Int $\mathrm{J}$ Biol Sci 7:301-307

Yoshitomi T, Hirahara K, Kawaguchi J et al (2002) Three T-cell determinants of Cry j 1 and Cry j 2, the major Japanese cedar pollen antigens, retain their immunogenicity and tolerogenicity in a linked peptide. Immunology 107:517-522

Yuki Y, Tokuhara D, Nochi T et al (2009) Oral MucoRice expressing double-mutant cholera toxin A and B subunits induces toxinspecific neutralising immunity. Vaccine 27:5982-5988
Yuki Y, Mejima M, Kurokawa S et al (2012) RNAi suppression of rice endogenous storage proteins enhances the production of rice-based Botulinum neurotoxin type A vaccine. Vaccine 30:4160-4166

Yuki Y, Mejima M, Kurokawa S et al (2013) Induction of toxinspecific neutralizing immunity by molecularly uniform ricebased oral cholera toxin B subunit vaccine without plantassociated sugar modification. Plant Biotechnol J 11:799-808

Zhang X, Buehner NA, Hutson AM et al (2006) Tomato is a highly effective vehicle for expression and oral immunization with Norwalk virus capsid protein. Plant Biotechnol J 4:419-432

Zhang X, Yuan Z, Guo X et al (2008) Expression of Chlamydophila psittaci MOMP heat-labile toxin B subunit fusion gene in transgenic rice. Biologicals 36:296-302

Zhang X, Yuan Z, Duan Q et al (2009) Mucosal immunity in mice induced by orally administered transgenic rice. Vaccine 27:1596-1600

Zhang XX, Yu H, Wang XH et al (2013) Protective efficacy against Chlamydophila psittaci by oral immunization based on transgenic rice expressing MOMP in mice. Vaccine 31:698-703 